\title{
Risk, Disappointment and Distraction in Keith Gessen's All the Sad Young Literary Men
}

James Peacock

\section{OpenEdition}

\section{Journals}

Electronic version

URL: https://journals.openedition.org/ejas/10252

DOI: 10.4000/ejas. 10252

ISSN: 1991-9336

Publisher

European Association for American Studies

\section{Electronic reference}

James Peacock, "Risk, Disappointment and Distraction in Keith Gessen's All the Sad Young Literary Men", European journal of American studies [Online], 9-1 | 2014, document 2, Online since 10 January 2014, connection on 08 July 2021. URL: http://journals.openedition.org/ejas/10252 ; DOI: https:// doi.org/10.4000/ejas. 10252

This text was automatically generated on 8 July 2021.

Creative Commons License 


\title{
Risk, Disappointment and Distraction in Keith Gessen's All the Sad Young Literary Men
}

\author{
James Peacock
}

1 It is, as Virginia Woolf observes, "very, very dangerous to live even one day" (12), and yet danger reminds us how impossibly, absurdly alive we are. Keith Gessen's debut novel All the Sad Young Literary Men, published in 2008, is very much concerned with different types of danger, with the risks its main characters take or imagine themselves taking as they attempt to make lives for themselves. As this article goes on to show, some of these risks, like confronting a tank in the occupied West Bank, put the young men in genuine physical danger. Others, like deciding to devote one's life to writing, present problems which are more to do with impecunity, loneliness and a predisposition to extended periods of paralyzing self-reflection.

2 For some readers, such inwardness is a serious weakness of Gessen's writing: the reviewer in New York magazine calls the opening chapters of the novel "self-satisfied" and "boringly solipsistic" ("Is This Book Worth Getting?"). Toby Lichtig, writing in The Guardian, is a little more measured but ultimately still expresses frustration.Arguing that semi-autobiographical musing on the life of the aspiring young writer is a trait the author needs to get "out of his system" before writing something with "a little more gravitas," Lichtig identifies the genre of Gessen's novel, somewhat dismissively, as "literary lad-lit" (24). Joyce Carol Oates, writing in the New York Review of Books, is far more complimentary. While acknowledging that Gessen's novel lacks the "magic" of the Fitzgerald short story collection from which it derives its "risky yet playful" title, she nonetheless praises the way the author has captured "the narcissistic ennui of privileged youth for whom self-flagellation is an art form" ("Youth!"). In other words, for Oates the solipsism and self-indulgence should be attributed to the characters, not necessarily to their author.

What all these reviewers recognize is the centrality of writing as a life choice, viable or otherwise, to Gessen's debut fiction. All the Sad Young Literary Men is about the 
consequences of pursuing the literary or intellectual life in an early twenty-firstcentury world increasingly fraught with danger, and one in which literature itself appears to be under threat from forms and media more suited to a culture of immediacy and rapid change. Although Gessen has not yet gained a public profile or a critical reception to match those of some of his contemporaries, for example Benjamin Kunkel and Chad Harbach, his first novel can be considered a revealing piece of evidence in the wider context of discussions about literature's contemporary status precisely because, for better or for worse, its characters spend so much time cogitating on the matter. And Gessen was, after all, one of the founding editors of the periodical $n+1$, along with Kunkel, Harbach, Mark Greif and Marco Roth. Born of disillusionment with the cultural scene in the United States, $n+1$ strives to rekindle meaningful debate and place literature and criticism at the center of things once more. In somewhat evangelical terms, A. O. Scott sees the editors of the magazine as trying to "organize a generational struggle against laziness and cynicism, to raise once again the banners of creative enthusiasm and intellectual engagement"; their work is "stirringly immodest" and sees culture "through eyes narrowed by skepticism" (38).

4 As well as this, presumably benign, skepticism, one might cite anxiety as another motivating factor: anxiety that worthy creative forms like the critical essay, the short story and especially, for reasons that shall become clearer, the novel are in danger of ceasing to be forms of activism and instead becoming marginalized, residual, outdated. It is an anxiety revealed in Kunkel's contribution to the 2011 collection The Late American Novel: Writers on the Future of Books. And, with a slightly different emphasis, it is one revealed in Kunkel's debut novel Indecision (2005), whose protagonist, Dwight Wilmerding, is crippled by postmodern irony and supposedly suffers from a condition known as abulia, or "chronic indecision" (Kunkel 33). His eventual political awakening and social activism constitute, as Adam Kelly observes, "a new kind of sincerity" ("From Syndrome to Sincerity" 54), albeit one the postmodern reader might still treat with a degree of suspicion. The novel Dwight narrates therefore becomes a testament to his sincerity and a model for action; it responds to Gessen's exhortation in the final lines of $n+1$ 's first number: "it is time to say what you mean." Saying what you mean and acting in concert with your beliefs is, of course, a risky strategy: it is far easier to relax into a non-committal, ironic stance.

5 All the Sad Young Literary Men demands, then, to be read in the context of the themes outlined in the introductory paragraphs of this article: the dangers of the contemporary world; the extent to which literature and the intellectual life can endure as forms of constructive activity; and whether sincerity and unironic engagement with a culture for so long characterized by knowingness and detachment is even possible. In the reading of the novel that follows, the three key terms of the title-"risk," "disappointment" and "distraction" are interlinked and their complex implications for Gessen's sad young literary men (and for novelistic practice more generally) unpacked. For synoptical purposes, one can express Sam, Mark and Keith's collective dilemma thus: disappointed with the state of contemporary America and with the way their romantic and professional lives have turned out, they are forced to confront the possibility that their immersion in bookish intellectualism has not produced significant action or even meaningful statements about the world, but has only been a form of distraction, a retreat from history and its important events. So they are forced to 
consider that for all its financial precariousness, the writing life may not be at all risky compared to the "real world."

6 Almost inevitably, this dilemma is exaggerated when set against the backdrop of the attacks on The World Trade Center in September 2001. Gessen's novel is not a "post-9/11" text in the manner of Lynne Sharon Schwartz's The Writing on the Wall (2005) or Don DeLillo's Falling Man (2007). It is not concerned, explicitly, with the aftermath of the attacks, even though it frequently refers to them. Like many "post-9/11" texts, however, it poses questions about the ability of writers to tackle big issues-tragedy, violence, history-and asks whether writing is essentially useless, nothing more than a pusillanimous withdrawal. Alison Kelly sums up the paradox of literary reactions to $9 / 11$ as "speechlessness versus loquacity" (52), the burning need to narrate the event versus the post-traumatic inefficacy of representational and linguistic strategies. This is the problem with which Sam, Mark and Keith wrestle throughout: how can their words possibly express the sheer enormity of present events? How can fiction compete with reality? And how can one experience the present while also staying in to write about what is happening?

7 Such questions have gained peculiar urgency and resonance since 11 September 2001, at least partly because other communication forms-primarily television, but also internet newsfeeds, social networking sites-seemed better able to keep pace and to capture the truly devastating images and stories. Therefore it is tempting to see the recent essay collection The Late American Novel: Writers on the Future of Books as in part a subliminal response to the questions of representational power and immediacy posed by the televised catastrophe. Where does the novel stand in the "instantaneous-opinion marketplace" (Lethem 131)? Is it "unreasonable" to have "some concern about "the future of the book' in the context of a world where more immediate diversions-music, movies, video games-are all readily available in the same portable device" (King 23)? And in a time when real events continually seem to outstrip one's capacity to fictionalize in startling ways, is it true that "the culture of literature, as opposed to that of commentary, threatens to become a subculture instead, or, better, a counterculture" (Kunkel 38)? When commentary-in the form of blogs, tweets, participation in reasoned online debates or hysterical ranting-is so quickly available, what place for the "[s]low-moving, slow-reacting, uselessly out of touch in the reaction-time marketplace" novel (Lethem 131)? In texts such as Philip Roth's Exit Ghost (2007) and Paul Auster's Man in the Dark (2008) this worry finds its metaphor in the figure of the ageing, impotent writer; what is striking about Gessen's story is that the sense of impotence has set in at the start of the young men's careers (if they can be dignified with such a word).

8 Having said that 9/11 has increased the urgency of these questions, it should also be stressed that they are not entirely new, even if the media technologies purportedly threatening the novel are. Philip Roth famously decried the paucity of fictional tools in representing American life in his 1961 essay "Writing American Fiction": "The American writer has his hands full, trying to understand and then describe and then make credible much of the American reality. It stupefies, it sickens, it infuriates, and finally it is even a kind of embarrassment to one's own meager imagination. The actuality is continually outdoing our talents, and the culture tosses up figures almost daily that are the envy of any novelist" (223). As this article goes on to demonstrate, it is vital to recognize the persistence of these ideas because it belies the belief that $9 / 11$ 
instantiated a radical conceptual break with everything that had preceded it. Instead, a consideration of certain continuities can offer the writer a way out of his or her perceived dilemmas: appreciate the impossibility of capturing "the present" (a complex idea in itself, as we shall see); understand that the novel's lack of immediacy is potentially virtuous, because it allows for a perspective on persistent truths rather than a series of discrete, cataclysmic moments, and then one might just rediscover the exciting risks involved in writing. If All the Sad Young Literary Men can be seen as a coming-of-age tale, then the characters' maturation consists in learning what these risks, and what the unique strengths of literature, really are.

When the reader first meets Sam, one of the three young men, it is clear that he initially sees his decision not to enter the conventional world of work and to stay at home and write "the great Zionist novel" (Gessen 35) precisely in terms of risk:

Sam did not have a chance. It had taken courage-not talent, not wit, and certainly not foresight-to refuse a regular job after school, to do nothing but read about Israel and worry and argue while his classmates found work at Fidelity or HyperCapital or joined rock bands or traveled the world. Sam knew he had more courage-they were taller, more attractive, they had better table manners and better skin, but he'd gotten all the balls. It took balls to do what he did because if he failed-and he had failed-he'd end up where he was. He hadn't accomplished the things of which he'd dreamed, and now he couldn't even get done the very basic things that most adults did [.] (93)

Later in the novel, realizing that things "[haven't] quite worked out" for him in the States, Sam travels to Jenin in the West Bank "on a journey for the discovery of certain facts. The facts on the ground" (163). His obsession with tank-spotting reveals his belief in military machinery as a material signifier of these "facts on the ground," and he is even prepared to criticize his Palestinian companions for the tanks' non-appearance: "This is how you fight the occupation? No wonder the tanks never come-all you guys do is try and pick up girls on the Internet" (192). After this amusingly hypocritical outburst, however, Sam's confused desires are met: wandering the streets with his Jeninian friends after curfew, he finally gets to experience real risk in the form of "a thing-an enormous, gigantic, hulking metal thing. Perhaps not so gigantic. But bigger than a horse, a lot bigger, and bigger than a pickup truck. A pretty big thing. A tank" (195). Momentarily, paralysis sets in: "The four of them froze. They were out after curfew and the tank could, theoretically, open fire. Those were the rules" (195). But when Mohammed lobs a stone at it, theoretical becomes actual and the friends are forced to run for their lives as the tank "[fires] madly behind them" (196). As it is described in this sequence, the tank is all size and material and fact-in brute contrast to Sam's abstract intellectualizing about the Middle East situation before his visit (and indeed about his whole life so far). It embodies, mercilessly, the very real risk of being out on the street rather than in his room, writing.

11 Typically for the early part of the novel, the epiphany it inspires is an ironic and bathetic one. Sam informs the reader that he survived, returned to the States and is now "preparing for law school" (196). Thus "the rules" alluded to in the quotation above, the terrifying martial law represented by the tank, accede to altogether less dangerous theoretical law. Sam has been exposed to serious danger, but is lucky enough to have the option of retreating to a safer environment where he "kept up with the news, sipped his beer, and thought about the future" (196). At least he is gracious enough to cite and acknowledge some of the fatalities that occur after he has left Jenin 
-"a British GIS member" killed by an Israeli sniper and an American shot in the face by "an Israeli armored personnel carrier" (196). And just maybe he has learnt something about the Middle East situation and appears to have given up on the great Zionist novel. As a project it was always impeded by, among many other things, including inertia and a preoccupation with sexual relationships overriding all other considerations, the fact that Sam "can't even read Hebrew" (40).

Part of the problem for Sam is the almost imperceptible (at least to him and the other young men) slippage from writing as a passionate engagement with ideas-the ideological history of Zionism, the disparate strands of Russian revolutionary philosophy, debates about American democracy as an engine of liberation and progress (Gessen 124)-to writing as a means of maintaining a sense of personal authenticity. At best this leads to "self-fulfilment or self-realization" (Taylor 29), a living of one's life "to the fullest" (Michaels 176). At worst, it is simply a means of filling time and gaining some kind of recognition (frequently measured in Google counts). In Walter Benn Michaels' somewhat schematic terms, such a slippage from ideology to ontology participates in the narrative of widespread critical decline in contemporary postmodernism (176). Benjamin Kunkel, in his analysis of Régis Debray's "Socialism: A Life Cycle," identifies a similar drift from a "myth of significant action" performed by novelistic and historical heroes "to a celebrity myth predicated on the apprehension of glamorous being" ("Goodbye" 33); that is, a shift to a spectacular ontology corresponding, Debray insists, with the supersession of the "graphosphere" (the printdominated era) by the "videosphere." Attendant on this epochal shift is a change in the apprehension of time. In the graphosphere, Debray sees temporality as linear, as "future-oriented"; in the videosphere, it becomes self-oriented" within a "cult of the present" (Debray 26).

13 Schematic though Debray's and Michaels' arguments are, they are nonetheless consonant in many respects with the thinking of other contemporary critics, notably Fredric Jameson, who shares Debray's concerns about the arrested and fetishized present in the postmodern, hypermediated world. And they are certainly relevant to Gessen's novel, which depicts aspiring young writers stalked constantly by their own disengagement from current affairs and tormented by the ontological spectacles of pornography and celebrity. Their anxiety about the present, and the consequent elevation in importance of the present, can be summed up with a rather banal but nonetheless significant statement: nothing much is happening to Gessen's three sad young literary men (apart from Sam's eventual encounter with the tank). Keith is a Harvard-educated writer living in New York City after a stint in Baltimore, who at one point has "a fellowship at a Washington think tank to write a postmortem on the 2000 election" (Gessen 145) but spends most of his time browsing internet pornography, aimlessly jogging, trawling through memories of his college days, and generally reflecting on sexual experiences missed and achievements unaccumulated. His firstperson narration best expresses the inertia and passivity afflicting all three of them: "I kept waiting for someone to tell me what they thought I should do, should be, what particular fate I, in particular, was fated for" (61). Boston-based Sam, as we have seen, is trying to write his great Zionist epic. Mark lives in bleak and dangerous Syracuse, where the papers are full of stories about girls locked in cellar dungeons and plans for America's biggest mall (Gessen 136). To reinforce the overall atmosphere of weary passivity, Gessen depicts Mark trying to complete a thesis on the Mensheviks, Russian revolutionaries altogether more thoughtful, less obstreperous and ultimately less 
successful than the better-known Bolsheviks. There are sexual relationships, the occasional party and eventually, as we have seen, the dramatic sequence in Jenin, but overall Gessen has imagined three lives which seem to bear out John Lennon's famous observation that "life is what happens to you when you're busy making other plans" ("Beautiful Boy").

But, of course, a lot does happen during the course of this novel, including 9/11, the Monica Lewinsky affair (Gessen 25) and the disputed presidential election of 2000 (31). It is just that there is for these young men an enervating disjunction between historical events and individual lives lived, frequently expressed as the tension between the event and speaking about or writing about the event, and resulting in numerous moments of ghastly narcissism. As Keith rightly says: "There is the event, which simply happens, and the interpretation, which never ends" (25). Far too often, however, Keith, Sam and Mark interpret these events only by appropriating them as allegories of their local obsessions, especially their troubled romantic lives, and therefore trivializing them. When the reader learns that "most of all Mark and Sasha and their friends worried about history and themselves," the fact that "[t]hey were right about Al-Shifa; they were right about the settlements" feels far less important than their more selfregarding questions: "What would happen to them? Were they good enough, strong enough, smart enough? Were they hard enough, mean enough, did they believe in themselves enough" (5). Such an emphasis on individual authenticity and self-worth in the face of historical events almost inevitably leads to the deliquescence of those events in petty everyday concerns. Reflecting on Bill Clinton's actions with reference to drunken college debates about "the definition of sex," Keith says: "We were disgusted by our President but secretly we lamented only that he hadn't done enough" (26). Monica Lewinsky becomes "another woman in our lives, so silly and so much like us" and the wider political implications of the affair and the possible impeachment process are ignored (26). For Keith at this early stage of the novel, "the great sociorelational problems of our time" are easily reducible to the complex and exciting sex life of his roommate Ferdinand (11).

The most extreme example of this allegorical tendency comes when Sam's "other woman" Arielle (Gessen 52) threatens to tell his girlfriend Talia about his infidelity and in so doing elicits this excruciating piece of free indirect discourse:

What a woman! She wanted a final settlement, and if she didn't have it she would drive him into the sea. It was land for peace-he gave up his moral land, his settlements on the territories of her conscience, allowed her the last word on everything, and she, in theory, would absolve and release and not tell Talia. He could promise her this. That was the thing to do; that was what men did. They promised and promised, and when it emerged that they'd been building settlements and buying arms all the while, they made incredulous faces and promised some more. (53)

16 This passage exemplifies the characters' shared problem. Having, as Mark observes, spent too much time in libraries (107), they feel sufficiently cut off from the reality of historical events to reduce these events to literary tropes in the pursuit of cleverer and more effective ways of expressing their own ineffectuality and alienation.

So while Al Gore's defeat might well constitute the paradigmatic disappointment of his generation, its shock value does little more than provoke from Keith another meditation on domestic inwardness in a relationship only ever supposed to last "until the next election" (9): "When they called the election back," he reflects, "we sat there 
together in disbelief. The diamond dangled on her finger like a fake... I was in shock, I was suddenly aware of my body, how foreign to me it had become, and Jillian's, as well, now pressed awkwardly against mine, and I wondered what would happen to us. We had become a little strange, living together all by ourselves. Jillian had to get up early for classes; I had to stay up late to write" (31). Staying up late to write pre-empts an active or bolshy response to the crisis and becomes another form of paralysis, unalleviated by the fact that paralysis is the very subject of the writing. Even the following pronouncement-"Ultimately these historical parallels were of limited use in figuring out your personal life" (211)-does not condemn the practice of selfallegorization. Rather it seems to condemn the historical events for their inefficacy as allegories of the young men's personal lives.

18 Their lack of utility stems partly, of course, from the arbitrary and scattergun manner in which Sam, Keith and Mark employ them. To cite but a few examples: Mark, distressed at the number of women who decide "to exercise their virtue" with him after shallow and disastrous sexual relationships with other men, decides that he is like Karl Liebknecht, "the German communist murdered in prison alongside Rosa Luxemburg after their bid for power failed in 1919" (104). Later he reflects on the difficulty of having two potential girlfriends in similarly overweening terms: "If meeting Celeste post-boyfriend was like arriving in Russia in March 1917, hopeful March after the tsar's abdication... then they were well into anarchic June or even forbidding July" (211). And Sam, perhaps the guiltiest of the three when it comes to allegorizing and trivializing, is bemused by images of Palestinians cheering the destruction of the World Trade Center, and muses: "In their ability to fuck up a late lead they were truly the equals of the Boston Red Sox" (56).

19 In at least the first two examples, the allegory seems to position the protagonist simultaneously in the present and the past, mentally in both the here-and-now and the elsewhere. What renders the young men's historical allegories essentially useless, however, is not simply their arbitrariness, but also the sense that the difference native to all extended metaphors (which is equal in importance to the assumed similarity of the figure), is exaggerated beyond any utility. In this case, for Mark to compare himself with Karl Liebknecht is not honestly to believe in their similarity, but instead to make a desperate bid to locate his banal present experience alongside something of historical importance which he nonetheless instinctively feels to be irreparably distant both chronologically and culturally from the present. When one conceives of history as discrete presents or epochs separated by ruptures, as these young men tend to do, then inevitably such supposed parallels cease to have any validity and one becomes paralyzed by the present.

20 Margaret Morse's essay “An Ontology of Everyday Distraction” (1998) provides a useful starting point for the theorization of the particular form of paralysis of which Gessen is writing. As Morse says, the novel, along with film and theatre, has traditionally been associated with "split-belief-knowing a representation is not real, but nevertheless momentarily closing off the here-and-now and sinking into another world" (99). The "attenuated fiction effect" of distraction (Morse 99) differs from split-belief in its complexity: "it involves two or more objects and levels of attention and the copresence of two or more different, even contradictory, metapsychological effects" (99). The "here-and-now" and the "elsewhere" are expressed and experienced simultaneously or alternately, rather than the here-and-now being temporarily closed off. Her well- 
known triumvirate of examples of "somewhat-less-than-real" non-spaces (103) includes the mall, the freeway and television. We might want to add, as another form of what she dubs, borrowing from Raymond Williams, "mobile privatisation" (Morse 100) the virtual travel between non-spaces facilitated by the Internet and portrayed in the Google searches and pornographic diversions of the three main characters.

Morse's closing reflections suggest strongly a spatiotemporal logic-a spatialized conception of the individual's inability to engage with the contemporary moment. Like Fredric Jameson she diagnoses in the postmodern treatment of history an enervating "spatial turn" (Jameson 154) influenced by the rise of the non-space. For example, the characteristic mode of representation dominated by "the segment" (Morse 123), familiar from news coverage in which screens are split, images juxtaposed and a "crawl" permanently rolls along the bottom of the screen, heightens the fiction effect by relaxing audience attention to one dominant image or narrative and demanding involvement with several representational planes at once. Rather than seeing in this a democratizing potential, however, Morse is concerned that it mirrors, or indeed precipitates, a deterioration in our appreciation of history as something that changes, develops and educates (123). In other words, so distracted are we by these segments that we fail to understand the larger historical, political and ideological processes at work. Moreover, such modes of representation speak to "the dominance of one set of values" over another-the exchange value of ideas in the marketplace over the free, discursive exchange of ideas (Morse 121).

It is worth observing briefly, in the light of Morse's ideas, how the non-spaces central to her argument come to dominate the lives and words of the characters. Most revealingly, Sam's reaction to his first encounter with an Israeli checkpoint in Jenin is to complain about the difficulty of finding a parking space in Cambridge, the fact that "sometimes you have to drive around for an hour" (171). Typically, this observation represents a pitiful inability to see the checkpoint for what it is-a non-space with genuine geopolitical significance, affecting the lives of individuals while influencing global political currents-and a solipsistic tendency to reduce it to an allegory of Sam's banal existence. Elsewhere, the planned mall in Syracuse becomes a constant presence in Mark's narrative, an example of twisted capitalist priorities in a town where a psychopath kidnaps young women and hides them in a "dungeon in his backyard" (114). And as I have already noted, the seismic moments of politics and history tend to be witnessed on television, in a distracted state; we are told, for example, that "[o]n the day the World Trade Center was destroyed, Sam watched a lot of television. When television went into a loop, he resorted to the Internet" (Gessen 55). Sam also panics about his shrinking Google count and wrongly interprets it as an ontological statement about his social reality (87). Mark erroneously even regards the horribly monikered "Buck Fuck Bus" porn site as a place where sexual reality occurs, far away from his library-bound existence (107-108).

It is precisely because the writing in which Sam, Mark and Keith labor is so hopelessly entangled with these other arenas of distraction that it ceases to operate at the level of split-belief and becomes a mode of distraction itself. It is, in Morse's terms, a derealized "non-space" between experience and representation (Morse 101), where discourse (that is, the life lived) and story (that is, the narration of that life) coalesce in a way that paralyses the writer, who finds him or herself unable to take risks or effect real change as he or she oscillates between different ontological dimensions. Moreover, the painful 
self-allegorizing in which these characters indulge-the use of historical events to portray their moribund relationships-coupled with Gessen's attention to cars, malls, television and the Internet, risks rendering his writing as distraction, too. It is so full of temporal disjunctions and representational layers and planes, so consumed with the anxiety of not being quite in the here-and-now, that it could almost be described as a fiction about the fiction effect, a veritable "phantasmagoria of the interior" (Morse 100). The interpolated pictures of Lincoln, Lewinsky and an email in-box-distractions both in the conventional sense and in Morse's more theoretical sense-only reinforce this view.

At the heart of the young men's anxieties lie questions about the very nature of "the contemporary" and how a writer can hope to access and express it. Their inertia is brought about partly because their desire to engage with contemporary events is inevitably thwarted by the temporal delay between event, thought and representation. In trying to portray contemporary events, in other words, one is neither here nor there, and finds oneself caught in a temporal non-space, always slightly disengaged from the present because one is always lagging behind, trying to write about it. Again, there is nothing particularly new about this dilemma, but it is surely intensified, as has been suggested, by the immediate visual impact of an event like the attacks on the Twin Towers, captured on mobile phone cameras and live TV broadcasts. How can a writer hope to compete with this? How can he or she be edgy, risky or controversial when he or she always arrives on the scene after the calamity has taken place? And how can socalled contemporary writing mean anything?

To offer a rebuttal posed as more questions: what if Keith, Mark and Sam are asking the wrong questions and misidentifying the problems? What if they are obsessed with the wrong kinds of events? And what if they are missing the true potential of All the Sad Young Literary Men and indeed of the novel as a form? To develop answers to these questions, and to edge tentatively toward a partially redemptive reading of a novel which is in many ways flawed and seems strangely unaware of its possibilities, it is useful to call upon an essay that remains one of the most cogent and persuasive formulations of the postmodern and notions of the contemporary: Jean-François Lyotard's “Answering the Question: What is Postmodernism" (1982). Lyotard's analysis is especially useful because it avoids the enervating spatiotemporal metaphors which, according to Timothy Bewes in his excellent article on Paul Auster, bedevil many discussions of the contemporary in the otherwise compelling work of Jameson, Michaels and, one might add, Margaret Morse. ${ }^{i}$ It therefore offers a way out of the paralysis that afflicts the young men and, perhaps, their author.

Central to Lyotard's argument is "[t]he sublime sentiment, which is also the sentiment of the sublime" (Lyotard 77). A "strong and equivocal emotion" which "carries with it both pleasure and pain" (77), the sublime consists in "a conflict between the faculties of a subject, the faculty to conceive of something and the faculty to 'present' something" (77). So the sublime is experienced when "the imagination fails to present an object which might, if only in principle, come to match a concept" (78). In a world of cultural "eclecticism" and diversifying tastes (76), a world in which science and industry are no more about the promulgation of certainties than the arts and humanities, one experiences "a kind of flight of reality out of the metaphysical, religious, and political certainties that the mind believed it held" (77). The sublime sentiment emerges in the impossibility of representing a reality that has become plural and elusive. For Lyotard, 
this "shattering of belief" and the attendant discovery of the "lack of reality' of reality" constitute modernity and lead to "the invention of other realities" (77) by means, partly, of experimental cultural forms.

But for all his talk of contemporary eclecticism and the influence of capital on taste (cultural value seen in terms of profit), Lyotard is not talking exclusively about a specific historical period, or indeed about the present. In contemplating modernity "in whichever age it appears," Lyotard strives "to free it from a narrowly historicized interpretation" (77) by suggesting that any work in any age developed "according to the sublime relation between the presentable and the conceivable" (79) participates in the modern. Moreover, postmodernism, far from signifying an epoch succeeding modernism, inheres within modernism; it is that which: "puts forward the unrepresentable in presentation itself; that which denies itself the solace of good ${ }^{\text {ii }}$ forms, the consensus of a taste which would make it possible to share collectively the nostalgia for the unattainable; that which searches for new presentations, not in order to enjoy them but in order to impart a stronger sense of the unpresentable" (81). If one accepts the sublime as Lyotard defines it, then this is a source both of pain-a sense of loss, of intangibility, of being unmoored-and pleasure-in new possibilities, freedom from stultifying norms.

So rather than indulging in nostalgia for lost reality or a crisis of confidence in an artist's ability to portray reality, the present or contemporary events, postmodern artistic practice describes the aspiration to new forms, a process of becoming distinct from "familiar categories" (Lyotard 81). For this reason, writers and other artists "are working without rules in order to formulate the rules of what will have been done. Hence the fact that work and text have the characters of an event" (Lyotard 81). Importantly, this kind of event is different from the news events obsessed over by Gessen's characters: it is, as Timothy Bewes says, "irreducible to any moment in timeirreducible, that is to say, to any single historicization" (Bewes 278) and, in Lyotard's thinking, conceived in paradox. Texts will "always come too late for their author, or, what amounts to the same thing, their being put into work, their realization (mise en oeuvre) always begin too soon" (Lyotard 81).

What is crucial here in relation to Gessen's novel and the anxieties it rehearses, is that the work can never be about historical events as such, only about "the relation between possibility and actuality" (Bewes 278). And by implication the present is something of which one can conceive but cannot represent; like cognition, it "is always notoriously in the place where it's not," allowing one to perform everyday actions which would otherwise break down if the individual were to stop and reflect on them. Thus the present, like reality, "is what one sees when one is not looking" (Tabbi 98). Or, in Bewes' words, "the present does not have any substantial actuality except in retrospect; except, that is to say, in imagination" (278). For Lyotard, the liberating potential of the postmodern text derives from this problematic temporality; it transcends mere commentary and is freed from any obligation to reflect on a particular historical moment precisely because it cannot. What it can do is formulate and apply new methods for the treatment of this impossibility and thus increase its own possibilities. In Jonathan Lethem's words, it can concentrate on "what it alone can dosubjectivity, language, eccentric unsupported supposition, deep expressionist lying" (Gates and Lethem 131). 

little of its potential pleasure. This is because they evidently want writing to be "political" and that "political" for them exists at the level of theme, content and their temporal proximity (or otherwise) to contemporary political events. Paralysis occurs when the writer realizes that anything he produces might only have significance fifty years in the future and that he cannot compete for immediacy with, say, the visual image or online commentary. There are two difficulties here. First, such a view assumes that "the present" can actually be experienced, measured and recorded, an assumption which Lyotard and Bewes show to be factitious. Thus a spatiotemporal conception of history as a series of presents punctuated with ruptures inevitably leads to paralysis and, moreover, belies the fact that the notion of what the "present" might be is itself ideological and subject to historicization. Yet such a conception is frequently revealed in the young men's observations. Most troublingly, Sam's belief that "the Holocaust happened under unique and terrible historical conditions, no longer ours" (Gessen 51) betrays an unwillingness to accept continuities, the danger of repetition or the ways in which a traumas such as the Holocaust inevitably disrupts attempts to represent it. that the novel can only be political by virtue of its thematic concerns, its immersion in "issues." Surely, however, literature is most political in terms of language and form, in, to cite Lyotard once more, its own potential as a process, an experiment and an "event." The tank to which this article has referred might be considered a clumsy attempt to encapsulate a contemporary situation by employing a hulking great symbol of risk, conflict, issues and history. To include this symbolic detail, as well as historical figures such as Clinton, Lewinsky and Gore, is not as risky a strategy as formal adventure and experiment.

Yet ultimately the novel does more than simply present a problem. Toward its conclusion it offers glimpses of a less melancholic outlook, one more sensitive to historical continuities and to the formal possibilities of the novel itself as a kind of event. As we shall see it is Keith-unsurprisingly, perhaps, given his likely similarities to the author-who provides the most telling glimpses, the most hopeful hints at a way out of the inertia he and his fellow young men have been suffering. It is he who begins to reveal a modified view of history not as presents and ruptures, but as continuities, and also as something much more imagined and amorphous, in which past, present and possible futures constantly interact to problematize the very notion of the contemporary "moment" and to inform and inspire change. This is something fundamentally different from the trivial allegorizing of one's experience through the use of historical figures and events. Instead, it exploits the potential of the novel's idiosyncratic temporality, brought about because a novel takes time to write and therefore cannot react to and comment on contemporary events in an instantaneous way. Rather than seeing this situation of being "too late" as enervating and a cause for anxiety, it is expedient to turn the curious temporal disjunctions it throws up to one's advantage.

Particularly pronounced in All the Sad Young Literary Men is a mode one might call "looking back on looking forward": in this narrative mode, characters evince a kind of nostalgia for prolepsis which is incessantly challenged both by signals within the narrative of how things really turned out and, more importantly, by the supplementary, though never complete, knowledge afforded the reader after the event. 
At times, this nostalgia is complexly multi-layered, as in Sam's reflections on the demise of his writing career: "The living writers of the world were Sam's enemies, Sam's nemeses. Sam was once a living writer himself, even better than a living writer, a future writer-there'd been a picture of Sam in one of the publisher's catalogs" (81). To think of himself as "the former future author of a Zionist epic" (97) is tacitly to acknowledge not simply his eventual failure, but also the fact that all feelings, impulses and affects-anticipation, disappointment, resignation-have a temporal aspect and only make sense when one is liberated from a fixation on the mythical present moment.

Moreover, as Adam Kelly argues, supposedly defining moments and defining feelings can never be represented as such ("Moments of Decisions" 326). They can only emerge through an oscillation between different possibilities made more unstable by the temporal event of the novel's writing and, in Kelly's insightful phrase, the "undecidable and unpredictable futurity of interpretation" (327). This is because any significant event-Gore's defeat, the arrival of the tank, the end of a romantic relationshipcontinues to disturb attempts to include it within a linear narrative, to fix it in time. Thus, in Paul Saint-Amour's words, working through such events requires a sense of "the future anterior, the 'will have been' that proleptically crystallizes a view of the past as seen from the vantage of the future" (63). This is precisely the characteristic mode of Gessen's novel. Time is "spatialized" (Saint-Amour 63), but not in the way Benn Michaels, Debray and to some extent Jameson and Morse conceive it; rather, it is an ethical space transcending simple linearity and allowing protagonist and reader to reflect on temporality itself, and on emotions and impulses evolving in time.

Saint-Amour's evocative image of "shrapnel" scattered across "the past and the future" (63) perfectly describes the power of what is the pivotal scene in the novel, when Keith returns to his family home in Maryland and browses the shelves of his mother's library:

I got up and walked into the little library off the main living room, filled with my mother's old books on Russian literature, most of them put out by the émigré presses-Ardis, L'Age d'Homme, YMCA-Presse. Like everyone else, she'd been forced into programming, Russians like some poorly dressed gang of programming mercenaries, but her old books from her old life had stayed, and occasionally I would look into them. The arguments no longer made much sense-over and over that Lenin was Stalin, that Brezhnev was Stalin, that if you didn't think so, you were Stalin-but the type, so clumsy and cheap, not mass produced and thin, like the Soviet books on the shelves, but as if an individual had gone into the DNA of every letter and somehow made it look awkward on the page, each letter in a different way-the type spoke of a world in which publishing these words and getting them to readers was the most important thing imaginable. I did not long for this world; I knew very well how much it cost; and I did not feel rebuked by it. But having been lived in once, by people I knew, and in these books-the world remained. Here was this library, transported from Moscow to Clarksville and finally down I-97 to the water. (154-55)

On the one hand, Keith yearns for a time when books mattered this much and when the passion of their production could be felt in the objects themselves. But he is careful to reject facile nostalgia: instead he recognizes certain continuities, political engagements still resonating. Most of all, in considering the materiality of the pages, the awkwardness of the print, he understands that whether or not the content is still relevant (and his mockery of the debates about Lenin, Stalin and Brezhnev suggests that it is not), the form, the book as an event, remains powerful. 

between his situation and the situation in which the books were produced, that allows him to appreciate both the continuities and the inevitable changes over time. Joyce Carol Oates, in her New York Times review of the novel, is therefore wrong to assert that the literary heritage evoked here is "secondhand" ("Youth!"). Such a word implies once again a view of history as discrete presents. What the library scene begins to reveal, however, is the idea that "everything one does reverberates through the universe eternally, so that there is no end to anything, technically speaking" (Gessen 237). Again, it is Keith who makes this claim, and again it suggests a much more amorphous temporality, one with ethical implications, one which demands a continuing sense of responsibility for one's actions rather than an egocentric desire to be "in the moment."

It is in light of these reflections that the ostensibly rather queasy optimism of the novel's final paragraphs can be interpreted. Keith, sitting in a local bar, thinks about his past relationship with Jillian, his present relationship with Gwyn, now pregnant, and the rash promises he has made to himself. He realizes, in the reinvigorated knowledge that nothing is ever truly finished, the futility of wishing "the things that had happened had not actually happened" (Gessen 241). And he remembers how he admonished himself after Jillian's departure: "No more proceeding on the basis of hope" (241). Yet from this rejection of hope as motivation he proceeds once more to a renewed optimism that inspires him to run home with a look to dissuading Gwyn from visiting the abortion clinic. His reasons for hope encapsulate both the best and the worst of the three sad young men:

Because it wasn't over yet, I thought, remembering my friends at Debate, my gentle social-democratic friends-there was still work to be done. A cabal of liars and hypocrites had stolen the White House, launched a criminal war, bankrupted our treasury, and authorized torture in our prisons. And now it was too late, as I have said-but also, you know, not too late. We had to live. And there were enough of us, I thought, if we just stuck together. We would take back the White House, and the statehouses and city halls and town councils. We'd keep the Congress. And in order to ensure a permanent left majority, Gwyn, we'd have many left-wing babies. My love. (242)

On the one hand, this reads like another desperate attempt to make Keith's ideas "political" by including overtly political content. Indeed, the decision to call this final section "2008" (the year of publication), might be seen as a last-ditch effort on Gessen's part to bring the content up-to-date. And whether or not Barack Obama's second term might yet reward some of the idealism and optimism expressed here, might even make it seem prescient, the passage ultimately appears to dodge the bigger question of how literature can reinstate itself as something other than a distraction, how it can be anything other than always-already "too late."

Yet, as I have been arguing, the virtue of the novel ultimately lies in its very inability to keep up with events. When Joyce Carol Oates calls the ending "wonderfully risky" ("Youth!") she is absolutely right. It takes the profound risk of expressing a hope that is almost certain, in the gap between possibility and actuality, between writing and readerly interpretation, to be proved misplaced. In the end, then, real risk has nothing to do with standing in front of a tank, giving up a steady job, or investing all your energies in self-validation through Google counts. It has everything to do with writing something which, in terms of analysis of contemporary events or predictions of the future, is almost bound to be proved dated, irrelevant or just plain wrong but which 
also, in terms of enacting its wrongness and allowing readers to reflect on it, creates an ethical space unbound by strict linear history. In such a space (distinct from the closed spaces Timothy Bewes perceives in many discussions of the postmodern), where interpretations interact and where the fully temporal nature of human emotions is emphasized, one can be comforted to know that we are all connected by disappointment, that disappointment is instructive and that it can precipitate action, not paralysis.

\section{BIBLIOGRAPHY}

Bewes, Timothy. "Against the Ontology of the Present: Paul Auster's Cinematographic Fictions." Twentieth-Century Literature 53.3 (Fall 2007): 273-97. Print.

Debray, Régis. “Socialism: A Life-Cycle.” New Left Review 46 (July-August 2007): 5-28. Print.

Gates, David, and Jonathan Lethem. "A Kind of Vast Fiction." The Late American Novel: Writers on the Future of Books. Ed. Jeff Martin and C. Max Magee. Berkeley: Soft Skull Press, 2011: 121-33. Print.

Gessen, Keith. All the Sad Young Literary Men. London: William Heinemann, 2008. Print.

"Is This Book Worth Getting? A No-Frills Guide to Five Just-Published New Novels." New York 21 (April 2008), 15 March 2012 <http://nymag.com/arts/books/features/46203/>. Web.

Jameson, Fredric. Postmodernism: Or, the Cultural Logic of Late Capitalism. London and New York: Verso, 1991. Print.

Kelly, Adam. "From Syndrome to Sincerity: Benjamin Kunkel's Indecision." Diseases and Disorders in Contemporary Fiction: the Syndrome Syndrome." Ed. T. J. Lustig and James Peacock. New York: Routledge, 2013. 53-66. Print.

---. "Moments of Decision in Contemporary American Fiction: Roth, Auster, Eugenides." Critique 51 (2010): 313-32. Print.

Kelly, Alison. “'Words Fail Me': Literary Reaction to 9/11.” 21: A Journal of Contemporary and Innovative Fiction 1 (Autumn-Winter 2008-9): 49-81. Print.

King, Owen. "Not quite as dire as having your spine ripped out, but..." The Late American Novel. 20-24. Print.

Kunkel, Benjamin. “Goodbye to the Graphosphere.” The Late American Novel. 31-39. Print.

---. Indecision. London: Picador, 2005. Print.

Lennon, John. “Beautiful Boy (Darling Boy).” Double Fantasy. Geffen. 1980.

Lichtig, Toby. "Pornography or Palestine? It's Hard Being a Young Man." Observer 27 April 2008: 24. Print.

Lukács, Georg. The Theory of the Novel: A Historico-Philosophical Essay on the Forms of Great Epic Literature. Trans. Anna Bostock. Cambridge, MA: MIT Press, 1971. Print. 
Lyotard, Jean-François. “Answering the Question: What is Postmodernism?” Trans. Régis Durand. The Postmodern Condition: A Report on Knowledge. 1984. Manchester: Manchester University Press, 2005: 71-82. Print.

Michaels, Walter Benn. The Shape of the Signifier: 1967 to the End of History. Princeton: Princeton University Press, 2004. Print.

Morse, Margaret. “An Ontology of Everyday Distraction: The Freeway, the Mall, and Television.” Virtualities: Television, Media Art, and Cyberculture. Bloomington and Indianapolis: Indiana University Press, 1998. Print.

Oates, Joyce Carol. “Youth!” Rev. of All the Sad Young Literary Men, by Keith Gessen. New York Review of Books 55.7 (1 May 2008), 15 March 2012. Web.

http://www.nybooks.com/articles/21316>

Roth, Philip. “Writing American Fiction." Commentary 31.3 (March 1961): 223-33. Print.

Saint-Amour, Paul K. "Bombing and the Symptom: Traumatic Earliness and the Nuclear Uncanny." Diacritics 30.4 (2002): 59-82. Print.

Scott, A. O. “Among the Believers.” New York Times 11 (September 2005): 38. Print.

Tabbi, Joseph. Cognitive Fictions. Minneapolis and London: University of Minnesota Press, 2002. Print.

Taylor, Charles. The Ethics of Authenticity. Cambridge, MA and London: Harvard University Press, 1991. Print.

Woolf, Virginia. Mrs Dalloway. [1925] London: Grafton, 1992. Print.

\section{NOTES}

i. It should be noted that Jameson acknowledges postmodernism's preoccupation with ruptures. It "looks for breaks, for events rather than new worlds, for the telltale instant after which it is no longer the same; for the 'When-it-all-changed,' as [William] Gibson puts it, or better still, for shifts and irrevocable changes in the representation of things and of the way they change" (ix). Bewes' point is that Jameson's use of spatial metaphors creates a kind of tautology or self-circuit in subscribing to the same preoccupations he describes.

ii. By "good" Lyotard means conventional, established, predictable.

\section{ABSTRACTS}

Keith Gessen's debut novel is not a "post-9/11" text in the manner of Falling Man or Terrorist. It is not concerned, explicitly, with the aftermath of the attacks. Like many "post-9/11" texts, however, it asks questions about the ability of twenty-first century writers to tackle big issuestragedy, violence, history. The three main characters-Sam, Mark and Keith-are Ivy Leagueeducated writers with an extensive knowledge of history, but have disengaged from history precisely because they live in books. This article explores the ways in which Gessen seems 
ironically to make writing the opposite of risk in an increasingly risky world. For these young men it becomes, along with Google searches and internet pornography, a form of distraction. Gessen poses a problem: writing has a responsibility to address historic events contemporaneously but increasingly, in competition with the visual image, only has power or purpose when viewed retrospectively as part of an earlier structure of feeling.

\section{AUTHOR}

JAMES PEACOCK

Keele University 